\section{Kvinnelig pekefinger og menn i hvitt}

Svare H.

\section{Menn i pleie og omsorg}

Brødre i hvitt. 252 s. Oslo: Universitetsforlaget, 2009. Pris NOK 299

ISBN 978-82-15-01535-4

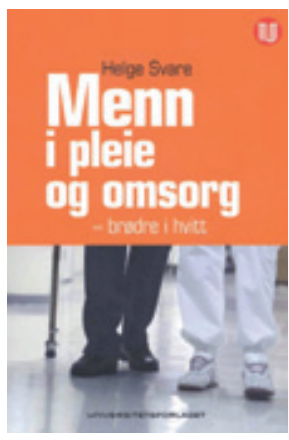

Selv om denne utgivelsen, som tittelen sier, handler om forhold rundt mannlige omsorgsarbeidere, fortrinnsvis sykepleiere og hjelpepleiere, får leseren mye mer med på kjøpet! Innledningsvis er det en glimrende og lett-

lest innføring i kjønnsideologi og kjønnsforskning, der forfatteren viser at han behersker sitt stoff. Det inngir tillit, ikke minst fordi mange bøker på dette feltet er skrevet av praktikere som får trang eller lyst til å skrive og resultatet ofte bærer preg av manglende litteraturoversikt og dårlig akademisk fremstillingsmåte. Svare har her etter min oppfatning lyktes i både å gi temaet en solid faglig forankring og samtidig gitt åpning for mange ikke-akademiske mannlige og kvinnelige stemmer fra grasrota.

«Den kvinnelige pekefinger» er et sentralt og interessant begrep. Det betyr i korthet at kvinnene bestemmer over mennene fordi de definerer standard for rydding og rengjøring. Et savn for meg som legeforsker er at legene og deres rolle i omsorgsarbeidet knapt er nevnt. Det slo meg da jeg leste de meget interessante refleksjonen rundt hvordan «den kvinnelige pekefinger» var en viktig årsak til at menn ikke slapp til i omsorgsarbeidet, at vi har et liknende fenomen blant legene, men med motsatt fortegn. Da jeg begynte mine medisinstudier i 1960-årene var bare $10-15 \%$ av studentene kvinner, i dag er det mellom $50 \%$ og $70 \%$. Mye av dette skyldes nok at «den mannlige pekefingeren» gradvis har mistet sin reisning. Det kunne vært interessant å se nærmere på om ikke legenes erfaringer kunne være nyttige ved en ønsket og tiltrengt reduksjon av kvinnedominansen i omsorgsyrkene.

Menn i pleie og omsorg er bygd rundt et forsøk ved et nyopprettet kommunalt bo- og behandlingssenter. Planen var å prøve ut en avdeling med mannlig avdelingsleder og minst $50 \%$ menn blant de ansatte. Denne målsettingen ble imidlertid ikke oppnådd avdelingslederen ble en kvinne, og på det meste var mannsandelen i personalet rundt $25 \%$. Likevel ga forsøket forskeren (forfatteren) en mulighet til å samle data om praktisk omsorgsarbeid, særlig i forhold til kjønnsforskjeller blant de ansatte. Data er dels intervjudata fra fokusgrupper og enkeltintervjuer, dels deltakende observasjon.

Som allerede nevnt håndterer Svare teorien på en overbevisende måte, og han viser seg også å være en dyktig forsker og forskningsformidler. Forskningen er forankret $i$ et samarbeidsprosjekt mellom Høgskolen i Telemark og Arbeidsforskningsinstituttet i Oslo. Menn i pleie og omsorg er lansert både som fagbok og som viktig for politikere og byråkrater, og jeg håper virkelig at noen i disse siste kategoriene tar seg tid til å lese. Om ikke så mange år er undertegnede en mulig kandidat for sykehjemsplass. Dersom noen av de grunnleggende problemene som Svare identifiserer var løst innen den tid, ville det vært fint. Og dersom noen av de konstruktive forbedringsforslagene hans virkelig var satt ut i livet, kunne jeg kanskje gå min siste tid lyst i møte!

\section{Olaf Gjerløw Aasland}

Legeforeningens forskningsinstitutt

\section{Grunnleggende om behandling av brudd}

Matre K, Hole RM, red.

Bruddbehandling

439 s, tab, ill. Trondheim: Legeforlaget, 2009 Pris NOK 430

ISBN 978-82-92934-03-6

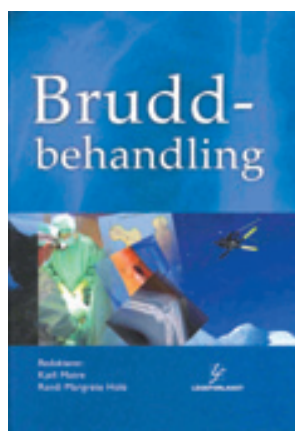

Det er et kurs med lange tradisjoner som nå utgis bearbeidet $\mathrm{i}$ bokform. De første årene het det Kurs i operativ bruddbehandling, siden har man undervist $i$ alle former for bruddbehandling.

Det første kurset ble arrangert ved

Ullevål sykehus høsten 1971, men allerede i 1972 flyttet det til Voss og ble arrangert som internatkurs. Kurset har i mange år vært obligatorisk for utdanningskandidater i generell og ortopedisk kirurgi, og hvert år har det vært laget et kompendium. Dette kompendiet har langt på vei vært brukt ved de fleste norske sykehus der brudd behandles.

Det er en betydelig oppgradering av kompendiet som nå utgis. Fortsatt er målgruppen først og fremst utdanningskandidater i generell og ortopedisk kirurgi. Forutsatt at det blir utgitt revideringer med korte mellomrom, vil dette være den viktigste metodeboken i bruddbehandling her i landet, også for spesialister i ortopedi.
Legevakter og akuttmottak bør ha denne tilgjengelig. På den måten kan primærvurderingen av skader få et nødvendig løft.

Det starter med et utmerket kapittel om det fysiologiske grunnlaget for brudd og bruddtilheling. Deretter kommer ett om funksjonell (ikke-operativ) bruddbehandling, før operativ behandling av alle vanlige (og noen mindre vanlige) brudd omtales systematisk etter anatomisk lokalisasjon. Brudd hos barn er viet et eget kapittel, likeså behandling av patologiske brudd. Det hele avsluttes med et kapittel kalt Komplikasjoner, men der omtales bare losjesyndrom og infeksjoner.

I alt har 21 forfattere bidratt. Med så mange bidragsytere er det naturlig at kvaliteten ikke er den samme i alle deler. Hovedinntrykket er likevel at det her formidles oppdatert og viktig kunnskap på en grei måte. Jeg kunne ha ønsket at kapitlene var bygd over en noe mer ensartet lest, der for eksempel diagnostikk, behandling, operasjonsteknikk, etterbehandling, komplikasjoner og resultater ble presentert. Dessverre er noe så viktig som komplikasjoner og resultater mangelvare i flere av kapitlene.

Noen innvendinger til tross - dette er en viktig utgivelse som gir gode retningslinjer for hvordan de forskjellige bruddtypene skal behandles. Både de to redaktørene og forfatterne fortjener ros for arbeidet, og det er god grunn til å vente at de fleste av svakhetene som finnes i denne første utgaven, vil være luket bort i den neste.

Norvald Langeland

Norsk pasientskadeerstatning

\section{Ultralyd 101}

Ødegaard S, Gilja OH, Matre K. Innføring i abdominal ultrasonografi

160 s, tab, ill. Bergen: Fagbokforlaget, 2009.

Pris NOK 388

ISBN 978-82-450-0727-5

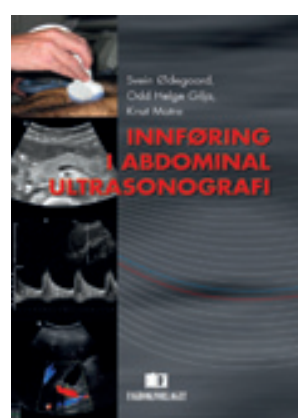

Denne boken gledet jeg meg til å lese, og etterpå var jeg mer enn fornøyd. Den gir en oversiktlig, velskrevet, passe grundig og inspirerende innføring i gastrointestinal ultralyd fra en gruppe som på ulikt vis har spredt det samme glade budskap i utallige fora de siste årene. Utgivelsen er et naturlig og etterlengtet ledd i dette arbeidet.

Oppbygningen er som forventet: En introduksjon om de fysiske prinsippene og 
begrepsdefinisjoner, et avsnitt om generell undersøkelsessystematikk, deretter en grundigere gjennomgang av undersøkelsen av de ulike abdominalorganene.

Mer avanserte modaliteter, inkludert motilitetsundersøkelser, kontrastundersøkelser og endoskopisk ultralyd, er også med, men uten å få mer plass enn det fortjener $i$ en utgivelse for denne målgruppen.

Som forfatterne selv skriver er Innføring $i$ abdominal ultralyd egnet for både nybegynnere og dem som har noe mer erfaring med ultralydundersøkelser av abdomen. I tillegg egner den seg altså som stimulerende appetittvekker for dem som har ment at ultralyd er viktigere enn den plassen det har fått $\mathrm{i}$ egen praksis. Det finnes en rekke mer omfattende lærebøker for dem som vil videre, men denne vil trolig få flere til å komme i gang.

Det er lite å utsette på denne utgivelsen. Den fortjener tilsvarende vid utbredelse i Norge, som et glimrende supplement til de øvrige utdanningstilbudene som etter hvert finnes innen gastrointestinal ultralyd.

\section{Lars Aabakken}

Medisinsk avdeling

Oslo universitetssykehus, Rikshospitalet

\section{Et viktig budskap}

Broeng S, red

Fokus på relationer

Psykiatri i praksis. 239 s, ill. København:

Hans Reitzels Forlag, 2009. Pris DKK 298 ISBN 978-87-412-5215-5

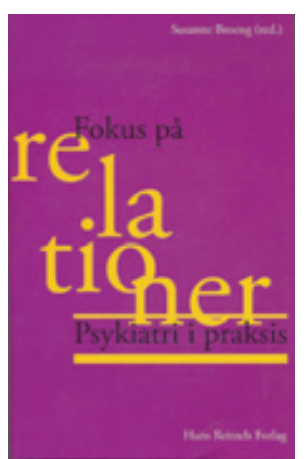

Ifølge redaktøren henvender man seg til «studerende og fagfolk inden for det sociale, psykologiske, sundhedsfaglige og pædagogiske område, det vil sige alle de forskjellige fagpersoner, der i deres arbeijdsliv møder patienter og pårørende og skal bidrage til at skabe udviklende processer for personer, der har fået diagnosticeret en sindslidelse». Vi får en innføring i betydningen av mellommenneskelige relasjoner i psykiatrisk behandling. I åtte kapitler beskrives historikk, teorigrunnlag og praksis på relativt bred front.

Fokus på relationer bør ønskes velkommen av flere grunner. For det første har vi innen psykiatrien vært vitne til en nesten eksplosiv økning i biologisk kunnskap. For det annet har økte krav om rask og effektiv «leveranse av helsetjenester» ført til vektlegging av raske prosesser og riktige håndgrep. Begge disse kan lett føre til at relasjo- nelle faktorer overses. Behandling står i fare for å bli en teknisk prosedyre hvor møtet mellom mennesker får lite rom. Her dokumenteres det på en etter min mening overbevisende måte hvor viktig det er å ta vare på mellommenneskelige relasjoner. Jeg tror at alle som arbeider i psykiatriske institusjoner vil ha utbytte av å lese dette, spesielt de mer praktisk rettede kapitlene.

Kapitlene om historikk og teori er mer ujevne. Den svakeste delen er etter min mening den som omhandler institusjonspsykiatriens historie. Den er mangelfullt beskrevet. Det er selvsagt en vanskelig avveining hvor mye man kan ta med $i$ en innføringsbok. Men hvis det skulle tas med et avsnitt om historien, burde man i hvert fall ha gitt plass til en omtale av det terapeutiske samfunn.

Et viktig spørsmål til slutt: Det er litt uklart hvordan denne utgivelsen er tenkt brukt. Den inneholder en del øvelser i form av rollespill og refleksjoner over eget liv. Disse øvelsene kan helt sikkert være meget verdifulle, men vil etter min oppfatning forutsette en kyndig ledelse. I boken sies det imidlertid ikke noe om det. Det burde ha vært noen råd om nødvendige rammebetingelser.

\section{Svein Friis}

Psykiatrisk divisjon

Oslo universitetssykehus, Ullevål

\section{Multidisiplinært om ungdom og seksualitet}

Magnusson C, Häggström-Nordin E, red. Ungdomar, sexualitet och relationer

376 s, ill, tab. Lund: Studentlitteratur, 2009. Pris SEK 373

ISBN 978-91-44-04934-2

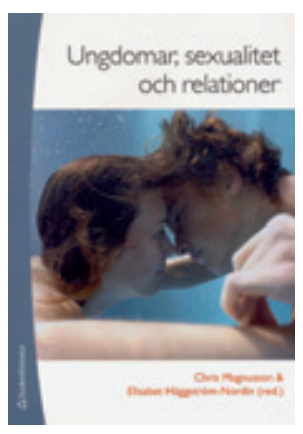

Utgiverne henvender seg til universitets- og høyskolestudenter samt faggrupper innen helsevesenet, skole og ellers i samfunnet. De ønsker at boken skal være anvendbar både i utdanning, innen sexologi og i praksis som grunnlag

for det forebyggende arbeidet. Den fremstår som en godt dokumentert lærebok der forfatternes intensjon er å gi et helhetsperspektiv på ungdom og seksualitet.

Det starter med presentasjon av de 16 forfatterne, representanter for myndighetene, virksomheter og forskning innen ulike disipliner, noe som til sammen gir et helhetsperspektiv på emnet. Tanken er at sek- sualitet ikke skal studeres som et isolert fenomen, men ses i større sammenheng. Hovedvekten ligger på det folkehelsevitenskapelige, det samfunnsvitenskapelige/ sosiologiske samt det psykologiske perspektivet. Innholdet strekker seg fra presentasjon av relevant forskning til at ungdommene selv får komme til orde i form av utdrag av en rekke samtaler og intervjuer fra ungdomshelsestasjoner og videregående skole.

Forfatterne redegjør for ulike aspekter av ungdommens seksuelle utvikling og atferd samt konstruksjon av kjønn og seksualitet, seksualitetens rolle $\mathrm{i}$ tenårene, reproduktiv helse og risikoatferd.

Kjønnsperspektivet kommer klart frem ved at gutter og jenter er omtalt $i$ egne kapitler. Særlig positivt er det at også spesielle grupper - de som er annerledes, med funksjonshemninger, har innvandrerbakgrunn - er viet egne kapitler der spesielle aspekter og behov kommer godt frem. De ulike innfallsvinklene gir et bredt og nyansert bilde av ungdom og seksualitet. Både positive og negative tendenser blir diskutert, og det vurderes også fremtidsvisjoner innen feltet. Til sammen gir dette en plattform som kan legges til grunn for planleggingen av forebyggende arbeid.

Språket er svensk, noe som kan være en utfordring å lese, særlig de kapitlene som er mest teoretiske og dermed mest preget av fagspråk. Hvert kapittel avsluttes med en lang og solid referanseliste, likevel blir teksten i flere av kapitlene forstyrret av et utall tekstlige referansehenvisninger i parentes. Med hell kunne henvisningene heller vært nummerert i forhold til referanselistene.

Det er kun noen få illustrasjoner og tabeller, det kunne gjerne vært flere. Gode illustrasjoner og bilder kan fremheve innholden i teksten og myke opp inntrykket. Ungdomar, sexualitet och relationer er i paperback, og trykkeprosess og innbinding har foregått på en miljøvennlig måte.

Som lærebok er dette en interessant utgivelse. Den er grundig og allsidig, ikke minst inneholder den mange nyttige referanser. Når den i tillegg omtaler seksualitet innen grupper i samfunnet det finnes lite annen litteratur om, bør den også kunne benyttes i praksisfeltet. Imidlertid må man være klar over at mye av stoffet beskriver svenske forhold, og at man ikke på alle områder kan trekke direkte paralleller til norske.

\section{Siv Gamnes}

Sex og samfunn

Senter for ung seksualitet

Oslo 